\title{
THE CAUSES OF THE BLACK STEM RUST EPIDEMIC IN FINLAND IN SUMMER 1951
}

\author{
by \\ ERKKI I. KIVI \\ Hankkija's Plant Breeding Station Tammisto, Helsinge \\ Received 12th Juni 1953
}

The black stem rust epidemic which prevailed in Northern Europe in the summer of 1951 also extended to Finland and had a very destructive effect on summer wheat fields $(5,8)$. The author presents below the results of his investigations, with special reference to the causes of the outbreak of the Finnish epidemic.

The black stem rust epidemic in Finland constituted part of the epidemic which fairly homogeneously involved the area from East Jutland and South Norway to Central Sweden, approximately to the latitude at which rust also found to the east of the Gulf of Bothnia (5).

Åkerman et al. (11) have shown that black stem rust was exceedingly abundant throughout the whole of South Sweden. The epidemic broke out there towards the end of July and became general in early August. The researches published in Sweden (11 etc.) indicate the possibility that the epidemic originated from spores, airborne from more southern regions. This interpretation is natural, sincethe barberry (Berberis vulgaris) is known to have been destroyed through legislative provision, not only in Scandinavia, but in other European countries as well (4). The German investigators Gassner and Pieschel (3), on the other hand, have shown that Puccinia graminis in the uredo stage is hardly able to over winter even in the Central-European climate. Nor have later researches demonstrated that black stem rust can winter, at least to any considerable extent, in Northern Europe.

Upon the outbreak of the epidemic in Denmark, thorough studies on the incidence of Berberis vulgaris were instituted, since the occurrence in Scandinavia was a quite isolated phenomenon, nor was there any epidemic elsewhere in Europe (12). The barberry was in fact found to be surprisingly abundant in different parts of Denmark $(6,10)$ and it was also present in Sweden to a greater extent than had been expected (1). Thereafter the conclusion was drawn that the epidemic had originated in the South of Fennoscandia, in regions in which Puccinia graminis tritici winters in the teleutosporic stage and where the prolific growth of Berberis 
vulgaris enables it to form abundant aecidiospores. Owing to the peculiar climatic conditions of the growth period in 1951, the spores spread extensively keyond their Berberis region, and the epidemic was of long duration, as the ripening of the wheat was exceedingly late (11).

\section{The North-European Epidemic}

In order to obtain a more complete picture of the extent of the epidemic and its duration, the author complemented the data supplied in previous investigations $(2,5,6,8,10,11)$ by written enquiries sent to numerous persons engaged in experimental work in Denmark, Norway, Sweden and Finland. On the basis of the information thus obtained and of the earlier investigations already referred to, the epidemic area assumes an outline illustrated i Figure 1.

In the north the epidemic ceases approximately at the northern border of the wheat-zone. The thinning out of fields of wheat is a factor which, affects the spread of the epidemic. Only meagre information was obtained from the northern epidemic area in Sweden, therefore this northern demarcation line has been drawn in a summary fashion.

According to written information received, the epidemic did not occur in Southwest Norway and West Jutland (also 2). A striking feature is the extension of the epidemic far into Northeast Finland (5).

The area where the epidemic broke out is referred to as the centre of the epidemic (Fig. 1). Some investigations $(6,10,11)$ and written data show that the epidemic first started in the province of Kalmar and Bornholm, and soon afterwards in East Götland, the Danish isles and Norwegian Vestføld. Elsewhere the epidemic began later. The simultaneous start in different parts of the centre of the epidemic suggests that Berberis vulgaris is not equally common throughout the area, but rather that the centre of the epidemic reported by the author could be subdivided into several central areas (such as Bornholm, Vestføld, Själland, the greak lake district of Sweden), but the available data do not allow of a more detailed analysis.

The epidemic was carried by the winds even beyond the confines of the Berberis area. To elucidate the modes of transmission, the author has collected data on anemological conditions in the Baltic Sea areas during the epidemic. These data have been collected at the Meteorological Research Institute (Helsinki) from their meteorological observations under the guidance of Miss Anni Parvi, M. A.

The wind observations showed that at the end of July, when the epidemic was beginning, very slight winds with rapidly changing direction prevailed in the entire south of Fennoscandia. The spores ewre thus carried in different directions, largely infecting the wheat fields in those parts of the centre of the epidemic in which the barberry occurred. This promoted a rapid simultaneous formation of uredospores, which was a very significant factor in the spread of the epidemic from its centre.

Later on west and south winds prevailed. The spores were then able to spread to the north and east, whereas the absence of an epidemic in West Jutland is 


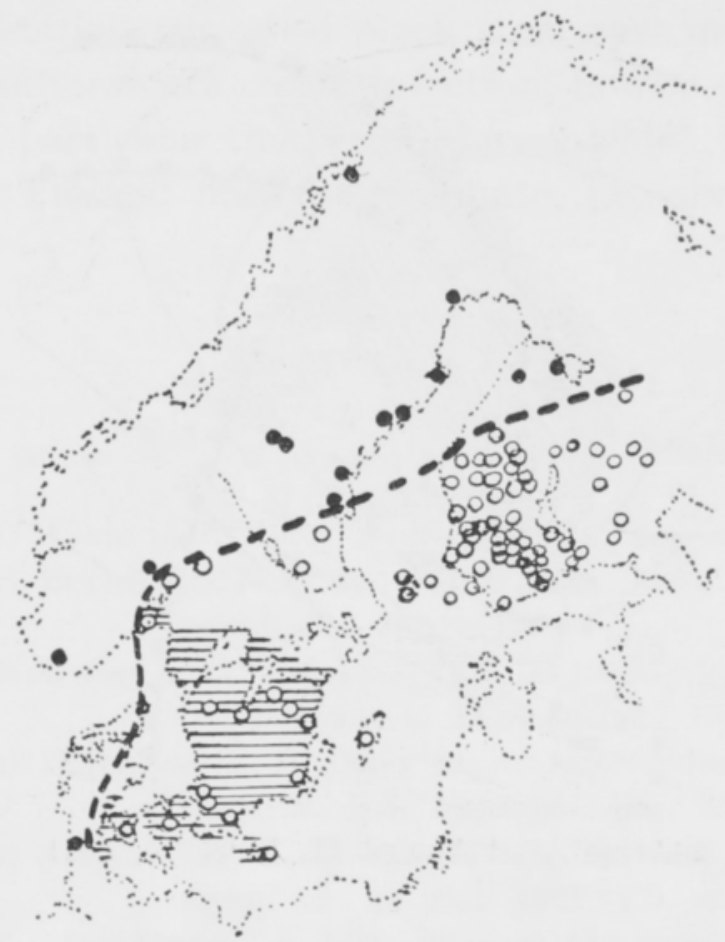

Fig. 1. Limit of the epidemic area of black stem rust in Northern Europe in summer 1951. The lines $=$ the centre of the epidemic, white dots $=$ rust has occurred, and black dots = no epidemic (according to (5) and own information).

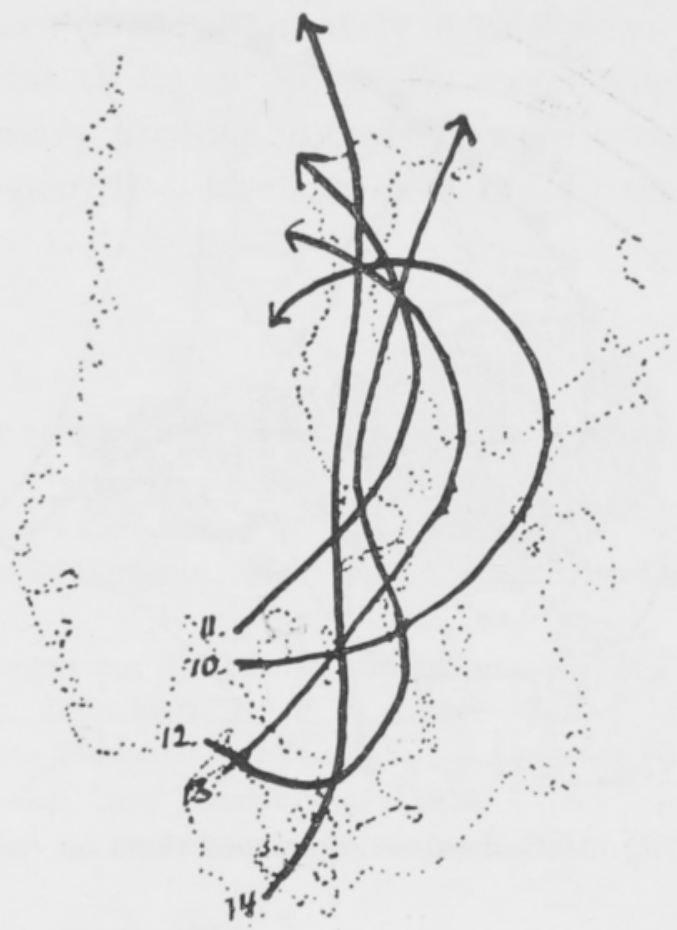

Fig. 2. Winds in the upper air calculated with the aid of gradient winds for the Baltic Sea area, August $10-14,1951$.

brobably due to the fact that west winds were blowing over the North Sea, preventing the spores from being borne westwards. In fact, in Denmark the epidemic was most pronounced in the eastern regions of the country (2). The run of the epidemic in Norway also shows that southwest and south winds had carried the spores in a northeasterly direction.

\section{The spread of black stem rust in Finland}

Berberis vulgaris is not indigenous in this country, but in gardens and other such places it has been found cultivated in different parts of Finland (5). Local outbreaks of rust are being found continually in this country. The writer assumes, however, that the violent epidemic in the summer of 1951 was carried from the South-Scandinavian and Danish centre of the epidemic. The question of the role played by endemic Berberis growth in the intensification and spread of the epidemic in Finland remains outside the scope of the present article.

In Finland Southwest air currents are general in laste summer. The wind observations made at South-Finnish meteorological stations show that 65 to 95 per cent of the winds in August, 1951, blew from westerly to southeasterly directions. These figures considerably exceed the average.

The intensity of the wind was, of course, highly variable, but on August 1012 especially, particularly strong southerly air currents prevailed. 

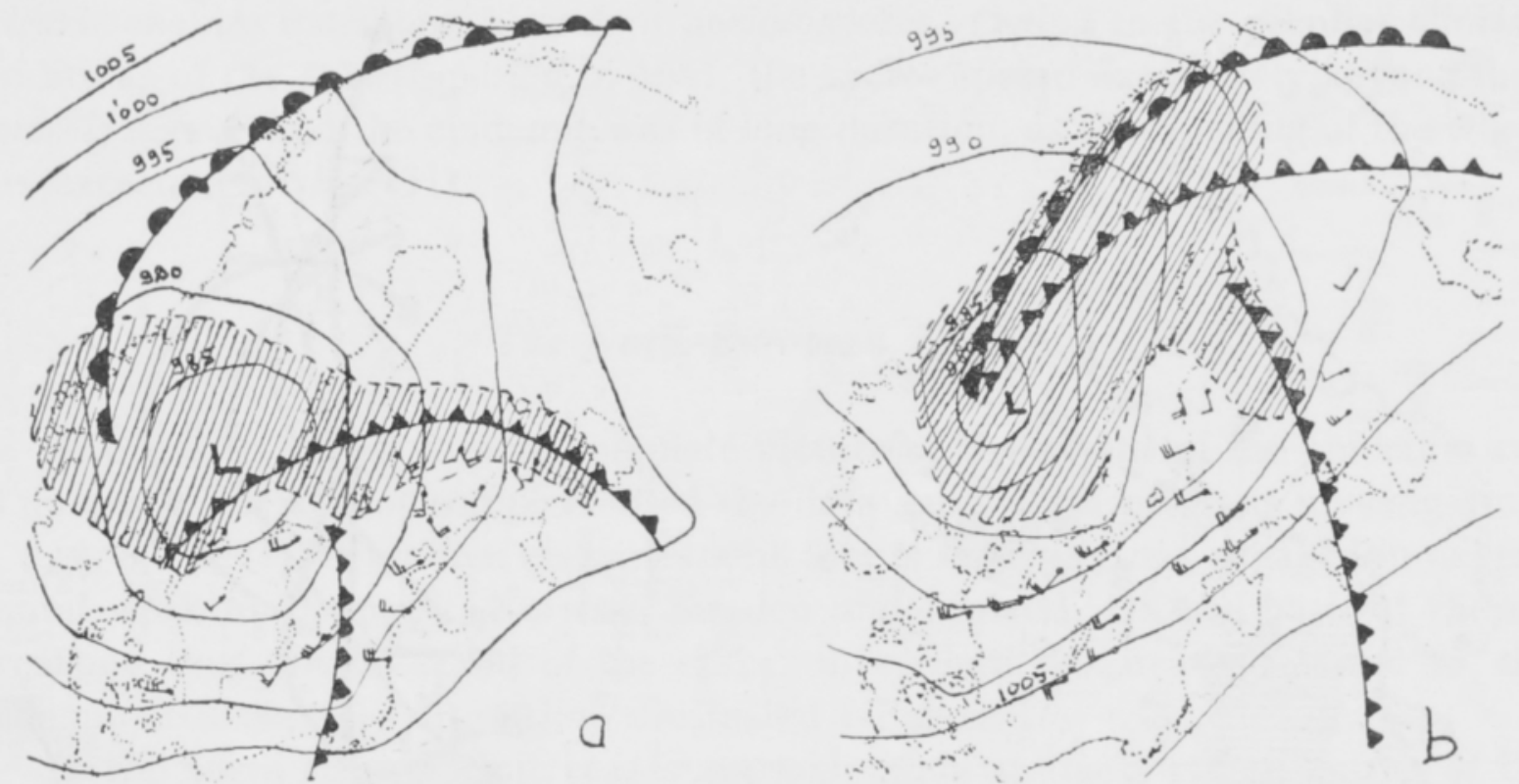

Fig. 3. General weather conditions on August 10, 20.00 (a), and August 11, 14.00 (b), 1951.

The winds in the upper air were also directed to the northwest, particularly in early August, and this current was most pronounced during the pentad August 10-14. The average for winds in the upper air calculated with the aid of gradient winds and shown in Fig. 2 for the said pentad, comprises the current which passes above the friction stratum at an altitude of about $600-1000 \mathrm{~m}$. Winds in the upper air and surface winds often have the same direction.

Fig. 3 shows the general trend of the air currents during the two consecutive observation periods of the pentad already mentioned. We note that the air fronts, i.e. the border lines between the cold and the warm zone, have gone in a northeast direction as well. The same figure also illustrates the rain areas. The summer of 1951 was on the whole very dry $(5,8)$, a significant factor in the wide distribution of the spores.

Since in order to reach Finland, the spores, must have been borne by the air current over fairly extensive water areas (the Baltic Sea, the Gulf of Bothnia or the Gulf of Finland), it would appear that the surface winds, rapidly changing in force and direction, could not alone have borne the initial amoint of spores emanating from a violent epidemic with a simultaneous outbreak in several different places. The most probable stratum of transportation seems to be the gradient wind area, to whose height the spores are able to rise without difficulty (9). The opportunity for such a rise was provided by the upward air currents of the pentad August 10-14. Since at that time the epidemic was general everywhere in South Sweden and in the eastern parts of Denmark, it is conceivable that huge amounts of spores had risen into the air and been borne to the northeast by gradient winds. The intervening rainy areas (Fig 3.) caused a downward was of the spores. Since the epidemic broke out after the middle of August simultaneously in Southwest Finland (my own observations, 8), in Uusimaa and in South Ostrobothnia (written information), the foregoing time of arrival of the spores appears most probable, since the ger- 
mination period of black stem rust uredospores is approximately 6 to 8 days $(7)$ The virulence of the infection, however, was due to an exceptionally warm August In particular the period during which the primary uredospores which were brough to Finland had to germinate, i.e. about August 10-12, was exceedingly warm

\section{I T E R A T U R E}

(1) ANerud, K. 1952. Svartrosten och dess härjningar. Lantmannen 62, 659-660.

(2) Buchwald, N. F. and Stapel, Chr. 1951. Sortrust og Berberis. Repr. from Ugeskrift for Landmaend, N:o 38, 1951.

(3) Gassner, G. and Pieschel, E. 1935. Untersuchungen zur Frage der Uredoüberwinterung der Getreideroste in Deutschland. Phytopath. Zeitschrift, Bd 7, H 4, 355-392.

(4) Hamilton, L. M. 1936. Recent information regarding Barberry and Barberry laws outside North America. U.S. Dept. of Agric. Bur of Entom. and Plant. Quar. 1936, 1-8.

(5) Jamalainen, E. A. 1953. Black Rust and occurrence of Berberidaceae in Finland. Journ. of Sci. Agric. Soc. of Finl. 1953, 47-53.

(6) Juen-Nilsen, A. 1952. Planteavl på Bornholm 1951. Rønne 1952.

(7) Lehmann, E., Kummer, H., and Dannenmann, H. 1937. Der Schwarzrost: seine Biologie und seine Bekämpfung in Verbindung mit der Berberitzenfrage. München/Berlin 1937.

(8) Pesola, V. A. and Kivi, E. I. 1952. Tutkimus mustanruosteen tuhoista v. 1951 Lounais-Suomessa, erityisesti lajikkeita ja vahingon määrää silmällä pitäen. Maatalous 1952, N:o 1, 7-11. (Repr. with english summary.)

(9) Stakman, E. C., Henry, A. W., Curran, G. C. and Christopher, W. N. 1923. Spores in the upper air. Jour. Agric. Res. 24, 599-606.

(10) Stapel, Chr. 1952. Paany til Kamp mod de farlige Berberisbuske. Repr. from Ugeskrift for Landmaend, No 21, 1952.

(11) Ånerman, Å., Mac Key, J., Holmgren, O., Wálstedt, I., Waller, E. and Torpe, N. 1952. Vid Sveriges Utsädesförening samlade erfarenheter från 1951 års svartrostangrepp å vete. Sv. Utsädesför. Tidskr. 1952, 65-151.

(12) Black Stem Rust (Puccinia graminis) in Europe in 1951. Misc. Publ. Europ. Plant. Prot. Organ. Paris, 2, 3 pp. 1952.

SELOSTUS:

SUOMESSA KESÄLLÄ 1951 VALLINNEEN MUSTARUOSTE-EPIDEMIAN SYISTÄ

ERKKI I. KIVI

Hankkijan kasvinjaiostuslaitos Tamisto, Helsingin pitäjä

Kirjoituksessa todetaan, että maassamme kesällä 1951 vallinnut vehnän mustaruoste-epidemia liittyi osana epidemiseen esiintymään, joka ulottui Tanskasta ja etelä-Norjasta keski-Ruotsiin ja Suomessa Kainuuseen saakka. $(2,5,6,8,10,11,12$. Tämän esiintymän primaarisena syynä olivat run saat Berberis-kasvustot $(1,2,5,7)$. Epidemian on todettu alkaneen juuri alueilla, missä happomarjapensasta runsaimmin esiintyi. Sitä aluetta tekijä nimittää epiddmiakeskukseksi (kuva 1). Kesän 1951 sääolot olivat epidemian alkamiselle ja leviäm. selle suotuisat $(5,11)$. 
Suomeen epidemia saapui epidemiakeskuksesta tuulien mukana. Ilmatieteellisen Tutkimuslaitoksen säätietojen mukaan ovat eteläiset ja lounaiset ilmavirtaukset olleet vallitsevia heinäelokuussa 1951. Todennäköisesti itiöt ovat saapuneet elokuun alkupuolella, jolloin puhalsivat yhtäjaksoiset lounaistuulet sekä pintakerroksissa että ylemmissä ilmakerroksissa (kuvat 2 ja 3 ).

Epidemia alkoi Suomessa samanaikaisesti Varsinais-Suomessa, Uudellamaalla ja Etelä-Pohjanmaalla elokuun puolivälin jälkeen.

\section{ARVI A. KARISTO OSAKEYHTIO}

Hämeenlinna . Puhelin 355।

\section{Kustannusliike. Graafiset tehtaat. Paperinjalostustehtaat.}

Kirjapaino • Kirjansitomo - Tilikirjatehdas - Viivauslaitos

Paperinjalostustehdas • Kirjekuoritehdas

Kuvalaattalaitos

Suorittavat alaansa kuuluvaa työtä kaikkialle maahamme.

Tuotteita myyvät maan kaikki kirja- ja paperikaupat.

\section{MAATALOUSTIETEELLINEN AIKAKAUSKIRJA}

\section{Ilmari Poijärvi \\ Päätoimittaja}

Tikkurila. Puh. 831244 ja 831308

E. Kitunen, J. O. Sauli, Erkki Kivinen, Aarne Virtamo

MAATALOUSTIETEELLISTÄ AIKAKAUSKIRJAA

ilmestyy 4 vihkoa vuodessa sisältäen kukin $2-4$ painoarkkia

Käsikirjoitukset lähetetään joko päätoimittajalle tai toimitussihteerille (os. Tikku= rila) tai jollekin toimitusvaliokunnan jäsenelle

\section{SUOMEN MAATALOUSTIETEELLINEN SEURA}

Puheenjohtaja:

Professori Onni Pohjakallio,

Viikin koetila, Malmi

Varapuheenjohtaja:

Professori Antti Mäki,

Mannerheimintie 35 B, Helsinki
Sihteeri :

Professori V. Vainikainen, Kasarmik. 38 A 8, Helsinki

Rahastonhoitaja :

Maisteri Aarne Virtamo. Maataloushallitus, Helsinki

Kirjastonhoitaja :

Maisteri Majlis Tulander, Hallituskatu 3, Helsinki 